\title{
Autonomy in participation in cerebral palsy from childhood to adulthood
}

\author{
ANN KATRIN SCHMIDT ${ }^{1,2, *}$ (D) | MARLOES VAN GORP ${ }^{1,3, *}$ (D) | LEONTIEN VAN WELY ${ }^{3}$ | MARJOLIJN KETELAAR \\ SANDER R HILBERINK ${ }^{1,5}$ | MARIJ E ROEBROECK ${ }^{1,2}$ | PERRIN-DECADE PIP STUDY GROUPS ${ }^{\dagger}$
}

1 Department of Rehabilitation Medicine, Erasmus MC, University Medical Center Rotterdam, Rotterdam; 2 Rijndam Rehabilitation, Rotterdam; 3 Department of Rehabilitation Medicine, Amsterdam Movement Sciences, Amsterdam UMC, Vrije Universiteit Amsterdam, Amsterdam; 4 Center of Excellence for Rehabilitation Medicine, Brain Center Rudolf Magnus, University Medical Center Utrecht and De Hoogstraat Rehabilitation, Utrecht; $\mathbf{5}$ Research Centre Innovations in Care, Rotterdam University of Applied Sciences, Rotterdam, the Netherlands.

Correspondence to Ann Katrin Schmidt, Erasmus MC, University Medical Center Rotterdam, Department of Rehabilitation Medicine, P0 Box 2040, 3000 CA Rotterdam, the Netherlands. E-mail: a.schmidt@erasmusmc.nl

*Shared first authorship.

${ }^{\dagger}$ Members of the PERRIN-DECADE and PiP study groups can be found in the Acknowledgements.

\section{PUBLICATION DATA}

Accepted for publication 20th August 2019

Published online

\section{ABBREVIATIONS}

PERRIN PEdiatric Rehabilitation Research in the Netherlands PiP Participation in Perspective RTP $\quad$ Rotterdam Transition Profile
AIM To determine the long-term development of autonomy in participation of individuals with cerebral palsy (CP) without intellectual disability.

METHOD Individuals with CP ( $n=189,117$ males, 72 females; mean age [SD] 21y $11 \mathrm{mo}$ [4y $11 \mathrm{mo}$, range $12-34 \mathrm{y})$; were assessed cross-sectionally (46\%) or up to four times $(54 \%)$, between the ages of 12 and 34 years. Autonomy in participation was classified using phase 3 of the Rotterdam Transition Profile. A logistic generalized estimating equation regression model was used to analyse autonomy in six domains (independent variables: age, Gross Motor Function Classification System [GMFCS] level, and interaction between age and GMFCS level). Proportions of autonomy were compared to references using binomial tests $(p<0.05)$.

RESULTS In most domains, over $90 \%$ of participants ( $n=189,400$ observations, $80 \%$ in GMFCS levels I and II) reached autonomy in participation in their late twenties, except for intimate/ sexual relationships. Those in GMFCS levels III to V compared to those in GMFCS levels I and II had less favourable development of autonomy in the transportation, intimate relationships, employment, and housing domains, and more favourable development in the finances domain. Compared to references, fewer individuals with CP were autonomous in participation.

INTERPRETATION This knowledge of autonomy may guide the expectations of young people with CP and their caregivers. Furthermore, rehabilitation professionals should address autonomy development in intimate relationships, employment, and housing, especially in individuals with lower gross motor function.
During their lifespan, individuals need to make several transitions that demand adaptability (e.g. entering secondary school or having a first romantic relationship or job). From this perspective, emerging adulthood is a challenging period since young people have to adapt to participating in new social roles and more complex life situations. ${ }^{1}$ Cardol et al. ${ }^{2}$ highlighted the importance of autonomy in participation, which can be described for several domains such as domestic life, interpersonal interactions and relationships, major life areas (education, employment, and economic life), as well as community, social, and civic life. ${ }^{3}$ Optimally, participation in these domains includes freedom to make decisions and act based on one's own attitudes and reasoning. These two latter constructs are also called decisional and executional autonomy. ${ }^{2}$ Achieving independence and developing self-determination in participation in adult roles might protect a person from disadvantaged participation outcomes and poor quality of life in the long-term. ${ }^{4}$

Development towards adult roles may provide additional challenges for individuals with a childhood-onset disability, such as cerebral palsy (CP). Individuals with CP have disorders of movement and posture that are often accompanied by cognitive, behavioral, or other impairments caused by non-progressive brain disturbances. ${ }^{5}$ Nowadays, since almost all children with CP reach adulthood, ${ }^{6}$ the transition into adulthood has gained ever-increasing interest in paediatric care. ${ }^{7}$ Although our knowledge of the 
development of autonomy in participation of individuals with CP from childhood into adulthood is limited, it could improve rehabilitation care since autonomy in participation is considered an important goal of rehabilitation care. ${ }^{2}$

In a previous phase of the PEdiatric Rehabilitation Research In the Netherlands (PERRIN) study, the Rotterdam Transition Profile (RTP) was found to validly assess an individual's phase of transition from being dependent on adults towards a self-reliant autonomous life in six domains of participation. ${ }^{4}$ Individuals with $\mathrm{CP}$ in their early twenties were found to lag behind in autonomy compared to typically developing peers. ${ }^{4}$ Furthermore, individuals with a lower level of gross motor functioning were less often autonomous in participation compared to those with a higher level. ${ }^{4,8}$ Knowledge of the development of autonomy in participation over time is limited because only cross-sectional studies and one study with a 2-year followup, are available for individuals with $\mathrm{CP}$ up to the age of 25 years. $^{7}$ Therefore, whether the development of autonomy over time differs between subgroups of individuals with $\mathrm{CP}$, such as those with lower versus higher levels of gross motor functioning, is unknown. Furthermore, regarding their autonomy, it is unknown whether individuals with $\mathrm{CP}$ continue to lag behind their age-matched peers up to their early thirties.

Insight into the long-term development of autonomy in participation of individuals with CP can guide the expectations of young people with $\mathrm{CP}$ and their caregivers, and may identify targets for rehabilitation care. The present study focuses on individuals without intellectual disability since they are expected to have the capacity to reach autonomy in adult life. For those with intellectual disability, adult roles may differ greatly, presenting other developmental goals that may require a different approach. ${ }^{4}$

This study aimed to: (1) describe the long-term development of autonomy in individuals with $\mathrm{CP}$ in several domains of participation from their teens into their early thirties and examine differences in development between individuals with high versus low levels of gross motor function; and (2) compare the proportions of individuals with $\mathrm{CP}$ who are autonomous in participation to the reference values of typically developing peers in the Netherlands.

\section{METHOD \\ Study design}

This study is part of the Dutch PERRIN programme. Participants were longitudinally assessed between 2000 and 2007 in four age cohorts: PERRIN 0-5 (baseline age: 12y); PERRIN 5-9 (baseline age: 5-7y); PERRIN 9-16 (baseline age: 9-13y); and PERRIN 16-24 (baseline age: 16-20y, three biennial assessments). Cohorts were considered representative of the population of individuals with $\mathrm{CP}$ since all individuals in rehabilitation care in the respective age ranges were invited to participate in the PERRIN study. We assumed that in the Netherlands almost all children with $\mathrm{CP}$ are in rehabilitation care. Two long-term follow-up studies were performed: the PERRIN

\section{What this paper adds}

- Individuals with cerebral palsy without intellectual disability achieved autonomy in most participation domains.

- Regarding intimate relationships, they continued to have less experience compared to age-matched references.

- Development of autonomy was less favourable for individuals in Gross Motor Function Classification System levels III to V.

Participation in Perspective (PiP), a 10-year follow-up study of PERRIN 0-5 and PERRIN 5-9; and the PERRIN-DECADE, a 13-year follow-up of PERRIN 9-16 and PERRIN 16-24. ${ }^{9,10}$ Observations from these follow-up studies and the previous biennial assessments of the PERRIN 16-24 cohort contributed to the present study. Previous observations from the PERRIN 0-5, PERRIN 5-9, and PERRIN 9-16 did not include assessments of autonomy in participation; consequently, they were added as cross-sectional data. Data were collected during interviews taking place in the home environment, except in the PERRIN PiP follow-up study (participant age range: $12-17 \mathrm{y}$ ), which collected data using online or paper-based surveys.

\section{Participants}

Details of the recruitment process of the four age cohorts are described elsewhere. ${ }^{4,11-13}$ For the present study, eligible participants had a clinical diagnosis of $\mathrm{CP}$ without intellectual disability, no additional diagnosis affecting gross motor function, and they or a representative could understand interviews conducted in Dutch or Dutch language questionnaires. Individuals were classified as having an intellectual disability if they had an IQ below 70 as assessed with the Snijders-Oomen Nonverbal Intelligence Test (PERRIN $0-5)^{14}$ or Raven's Coloured Progressive Matrices (PERRIN 5-9), ${ }^{15}$ or based on educational level (those following a special education programme for individuals with severe intellectual disability [PERRIN 9-16 and PERRIN 16-24]). ${ }^{11}$ Former participants of the cohorts were recruited through information letters. ${ }^{9,10}$ In total, 189 participants were included: 143 participated in the longterm follow-up studies and 46 PERRIN 16-24 participants who did not participate in the 13-year follow-up were included from the existing PERRIN database (Appendix S1, online supporting information). Of all participants, 90 were assessed longitudinally either up to 4 $(n=35)$ or 13 years $(n=55)$.

\section{Measures}

\section{Autonomy in participation}

The development of autonomy in participation was monitored using the Dutch language version of the RTP, which is validated to classify phases of transition into adulthood. ${ }^{4}$ Decisional and executional autonomy are addressed along with the phases of transition for six domains of participation: leisure (social activities); transportation; finances; intimate/sexual relationships; education and employment (hereafter referred to as employment); and housing. For each domain, the most appropriate phase of transition was scored as follows: having no experience (phase 0); being 
dependent on adults (phase 1); experimenting and orientating to the future (phase 2); being self-reliant or autonomous (phase 3). Phase 0 is not applicable for the domains housing and transportation. ${ }^{1}$ Specific descriptions of the transition phases for each domain are shown in Appendix S2 (online supporting information). Autonomy in participation (phase 3) specifically referred to: going out in the evening with peers (leisure); organizing transportation independently (transportation); being economically independent, having a paid job, or receiving disability benefits (finances); having had experience with sexual intercourse (intimate relationships); having a job, sheltered, paid, or unpaid employment (employment); and living independently, including assisted living while making one's own decisions regarding domestic life (housing). Appendix S2 presents the 2011 version of the RTP (original Dutch version) that was used for the long-term followup.

\section{Demographic and clinical characteristics}

Age and level of education were recorded at each assessment (except for the level of education for the PERRIN PiP cohort). Three levels of education were distinguished according to the International Standard Classification of Education 2011: (1) low (lower secondary education or lower); (2) medium (upper secondary education and postsecondary non-tertiary education); and (3) high (short-cycle tertiary education, higher professional education, or university). ${ }^{16}$ The type of motor impairment and level of gross motor function were recorded at baseline. The type of motor impairment was classified as spastic unilateral, spastic bilateral, or mixed (dyskinetic, ataxic, and mixed CP). ${ }^{17}$ The Gross Motor Function Classification System (GMFCS) was used to classify motor function in five levels ranging from walking without limitations (GMFCS level I) to severe limitations in self-mobility (GMFCS level V). ${ }^{18}$

\section{Statistical analysis}

Descriptive statistics were computed for the demographic and clinical characteristics and for the distribution of RTP transition phases at different ages $(12-14 \mathrm{y}, 15-18 \mathrm{y}, 19$ $22 y, 23-26 y, 27-30 y$, and 31-34y). In addition, the age when $50 \%$ of the sample had reached autonomy in participation (phase 3) was described. For the remainder of the analyses, the transition phases were dichotomized (phase $0-2$ vs phase 3 [autonomy]). GMFCS levels were also dichotomized (I and II vs III-V). ${ }^{19}$ A logistic generalized estimating equation regression model was used for the outcome 'autonomy' (yes/no) in each specific domain. Independent variables were age, GMFCS level (I and II as the reference category), and the interaction between age and GMFCS level. The model was adjusted for dependency of observations within one individual; it also allows cross-sectional assessments because it handles missing data appropriately. The model provided estimates of the effect of GMFCS level (I and II vs III-V), age, and the interaction of these on the odds of having achieved autonomy over time. For a correct interpretation of odds ratios (ORs), age was standardized by subtracting the mean. An OR greater than 1 indicates larger odds of autonomy, while an OR smaller than 1 indicates smaller odds of autonomy. The OR for GMFCS levels III to $\mathrm{V}$ indicates the difference in odds of individuals in GMFCS levels III to $\mathrm{V}$ compared to those in GMFCS levels I and II. For age, the OR indicates the odds for each year an individual in GMFCS levels I and II is older. Finally, the interaction indicates the odds of autonomy for each year an individual in GMFCS levels III to $\mathrm{V}$ is older.

Autonomy in participation of individuals with $\mathrm{CP}$ was compared with that of Dutch age-matched reference peers using two-tailed, one-sample binomial tests in 5-year age intervals $(15-19 y, 20-24 y, 25-29 y$, and 30-34y). Data from the general population were extracted from the database of Statistics Netherlands (StatLine, https://opendata.cbs.nl/sta tline/\#/CBS/nl/) for finances (income through employment or receiving benefits) and housing (living independently); ${ }^{20,21}$ reference data for intimate relationships (sexual intercourse within the last $12 \mathrm{mo}$ ) were obtained from Rutgers/Soa Aids Nederland. ${ }^{22}$ No suitable reference data were available for employment, leisure, and transportation.

Analyses were performed using SPSS v24.0 (IBM Corp., Armonk, NY, USA). The significance level was set at $p<0.05$.

\section{Ethical considerations}

Approval for the cohort studies was obtained from the medical ethics committees of all participating centres. The medical ethics committees of UMC Utrecht (for the PERRIN PiP study), Amsterdam UMC (location VUmc), and Erasmus MC Medical Center Amsterdam/Rotterdam (for the PERRIN-DECADE) agreed that the long-term follow-up studies were outside the scope of the Medical Research Involving Human Subjects Act. All participants, or their legal representatives, provided written informed consent.

\section{RESULTS}

The 189 participants contributed to 400 observations (Appendix S3, online supporting information). The number of observations by outcome (and age category) are shown in Tables 1 and 2 and Figure 1. Participants' (117 males, 72 females) ages ranged from 12 to 34 years, $80 \%$ were in GMFCS level I or II, and $88 \%$ had a spastic subtype of CP (49\% unilateral and $51 \%$ bilateral spastic CP). Participants' characteristics are shown in Appendix S4 (online supporting information).

\section{Transition into adulthood}

Figure 2 shows the distribution of development of autonomy in the six domains of participation according to age. For transportation, most individuals were autonomous from age 13 years onwards; for leisure, finances, intimate relationships, and employment, most individuals were autonomous from age 18 to 22 years onwards; for housing, 
Table 1: Time course for the total cohort in six participation domains of the Rotterdam Transition Profile according to Gross Motor Function Classification System (GMFCS) level

\begin{tabular}{|c|c|c|c|c|c|c|c|c|}
\hline & \multicolumn{4}{|c|}{ Leisure (social activities) } & \multicolumn{4}{|c|}{ Transportation } \\
\hline & $n^{\mathrm{a}}$ & OR & $95 \% \mathrm{Cl}$ & $p$ & $n^{\mathrm{a}}$ & OR & $95 \% \mathrm{Cl}$ & $p$ \\
\hline Age & 294 & 1.71 & $1.34-2.17$ & $<0.001$ & 299 & 1.57 & $1.34-1.83$ & $<0.001$ \\
\hline GMFCS levels III- $\mathrm{V}^{\mathrm{b}}$ & 294 & 0.56 & $0.09-3.57$ & 0.536 & 299 & 0.12 & $0.03-0.43$ & 0.001 \\
\hline \multirow[t]{3}{*}{ Interaction between age and GMFCS levels III- $\mathrm{V}^{\mathrm{b}}$} & NA & NA & NA & NA & 299 & 0.85 & $0.60-1.20$ & 0.355 \\
\hline & \multicolumn{4}{|c|}{ Finances } & \multicolumn{4}{|c|}{ Intimate relationships } \\
\hline & $n^{\mathrm{a}}$ & OR & $95 \% \mathrm{Cl}$ & $p$ & $n^{\mathrm{a}}$ & OR & $95 \% \mathrm{Cl}$ & $p$ \\
\hline Age & 388 & 1.56 & $1.40-1.73$ & $<0.001$ & 397 & 1.28 & $1.19-1.37$ & $<0.001$ \\
\hline GMFCS levels III- $\mathrm{V}^{\mathrm{b}}$ & 388 & 5.05 & $1.29-19.77$ & 0.020 & 397 & 0.29 & $0.14-0.62$ & 0.001 \\
\hline \multirow[t]{3}{*}{ Interaction between age and GMFCS levels III- $\mathrm{V}^{\mathrm{b}}$} & 388 & 1.23 & $0.87-1.73$ & 0.235 & 397 & 0.98 & $0.87-1.11$ & 0.773 \\
\hline & \multicolumn{4}{|c|}{ Education and employment } & \multicolumn{4}{|c|}{ Housing } \\
\hline & $n^{\mathrm{a}}$ & OR & $95 \% \mathrm{Cl}$ & $p$ & $n^{\mathrm{a}}$ & OR & $95 \% \mathrm{Cl}$ & $p$ \\
\hline Age & 396 & 1.63 & $1.45-1.82$ & $<0.001$ & 400 & 1.47 & $1.37-1.58$ & $<0.001$ \\
\hline GMFCS levels III-V & 396 & 0.71 & $0.34-1.45$ & 0.347 & 400 & 0.66 & $0.30-1.44$ & 0.294 \\
\hline Interaction between age and GMFCS levels III- $\mathrm{V}^{\mathrm{b}}$ & 396 & 0.78 & $0.66-0.93$ & 0.005 & 400 & 0.81 & $0.72-0.91$ & $<0.001$ \\
\hline
\end{tabular}

${ }^{a}$ Total number of observations in the models. The number of observations varied due to study design; the leisure and transportation domains were added later throughout the development of the Rotterdam Transition Profile. ${ }^{\mathrm{b}}$ Reference category: GMFCS levels I and II. $\mathrm{OR}$, odds ratio; $\mathrm{Cl}$, confidence interval; $\mathrm{NA}$, not applicable (model is inappropriate for the data).

Table 2: Proportions of autonomy in finances, intimate relationships, and housing in individuals with cerebral palsy (CP) and the Dutch age-matched population

\begin{tabular}{|c|c|c|c|c|c|c|c|c|}
\hline \multirow[b]{2}{*}{ Age, y (range) } & \multicolumn{4}{|c|}{ Finances (independent life, phase 3 ) } & \multicolumn{4}{|c|}{ Intimate relationships (independent life, phase 3 ) } \\
\hline & 15-19 & $20-24$ & $25-29$ & $30-34$ & 18-19 & $20-24$ & $25-29$ & $30-34$ \\
\hline $\mathrm{CP}(\%)$ & $21.9^{\mathrm{a}}$ & $64.4^{\mathrm{a}}$ & 93.3 & 97.9 & $20.8^{\mathrm{b}}$ & 50.3 & 60.0 & 74.5 \\
\hline Dutch general population (\%) & 54.2 & 78.7 & 89.6 & $95.2^{\mathrm{c}}$ & 50.6 & 78.6 & 88.2 & 91.8 \\
\hline Binomial test $(p)$ & $<0.001$ & $<0.001$ & 0.768 & 0.668 & $<0.001$ & $<0.001$ & $<0.001$ & $<0.001$ \\
\hline Age, y (range) & $20-24$ & $25-29$ & & & & & & \\
\hline
\end{tabular}

Housing (independent life, phase 3)

\begin{tabular}{llc}
\hline $\mathrm{CP}(\%)$ & 32.7 & 63.3 \\
Dutch general population (\%) & 50.1 & 83.5 \\
Binomial test $(p)$ & $<0.001$ & 0.012
\end{tabular}

Number of observations at subsequent age intervals for CP: 147 (15-19y); 162 (20-24y); 30 (25-29y); 47 (30-34y). ${ }^{a}$ Missing data for finances $(15-19 y, n=10 ; 20-24 y, n=2)$ and intimate relationships $(20-24 y, n=3)$. b Number of observations at age $18-19 y$ for $C P, n=77$. ${ }^{\mathrm{c}} \mathrm{Age}$ in the Dutch general population, 30-32y.

most individuals were autonomous from 27 years of age. Overall, at 27 years of age and older, in each of the participation domains, $90 \%$ of individuals with $\mathrm{CP}$ were autonomous, with the exception of intimate relationships, for which the proportion of autonomous individuals levelled off at slightly over $70 \%$.

\section{Longitudinal development of autonomy in participation}

The generalized estimating equation analyses (Fig. 1) show that the proportions of autonomous individuals with $\mathrm{CP}$ increased with age. Table 1 presents the model parameters. In addition, for transportation and intimate relationships, lower proportions of individuals in GMFCS levels III to V

Figure 1: Proportions of individuals with cerebral palsy in phase 3 of the Rotterdam Transition Profile over time, specified by Gross Motor Function Classification System, and presented in age categories of 4y. Number of observations at subsequent age intervals for cerebral palsy: 14 (12-14y); 108 (15-18y); 147 (19-22y); 73 (23-26y); 21 (27-30y), 37 (31-34y). Due to missing data, the number of observations were as follows: leisure (social activities) (15-18y, $n=45$; 19-22y, $n=107$; 23-26y, $n=72)$; transportation (15-18y, $n=45$; 19-22y, $n=109$ ); finances (15-18y, $n=100 ; 19-22 y, n=144 ; 23-26 y, n=72)$; intimate relationships (19-22y, $n=146 ; 23-26 y, n=71$ ); education and employment (19-22y, $n=144 ; 23-26 y, n=72)$. The dashed line indicates the proportions of autonomy of the Dutch age-matched population; this added for visual estimation, whereas binomial tests are presented on the total study population. 

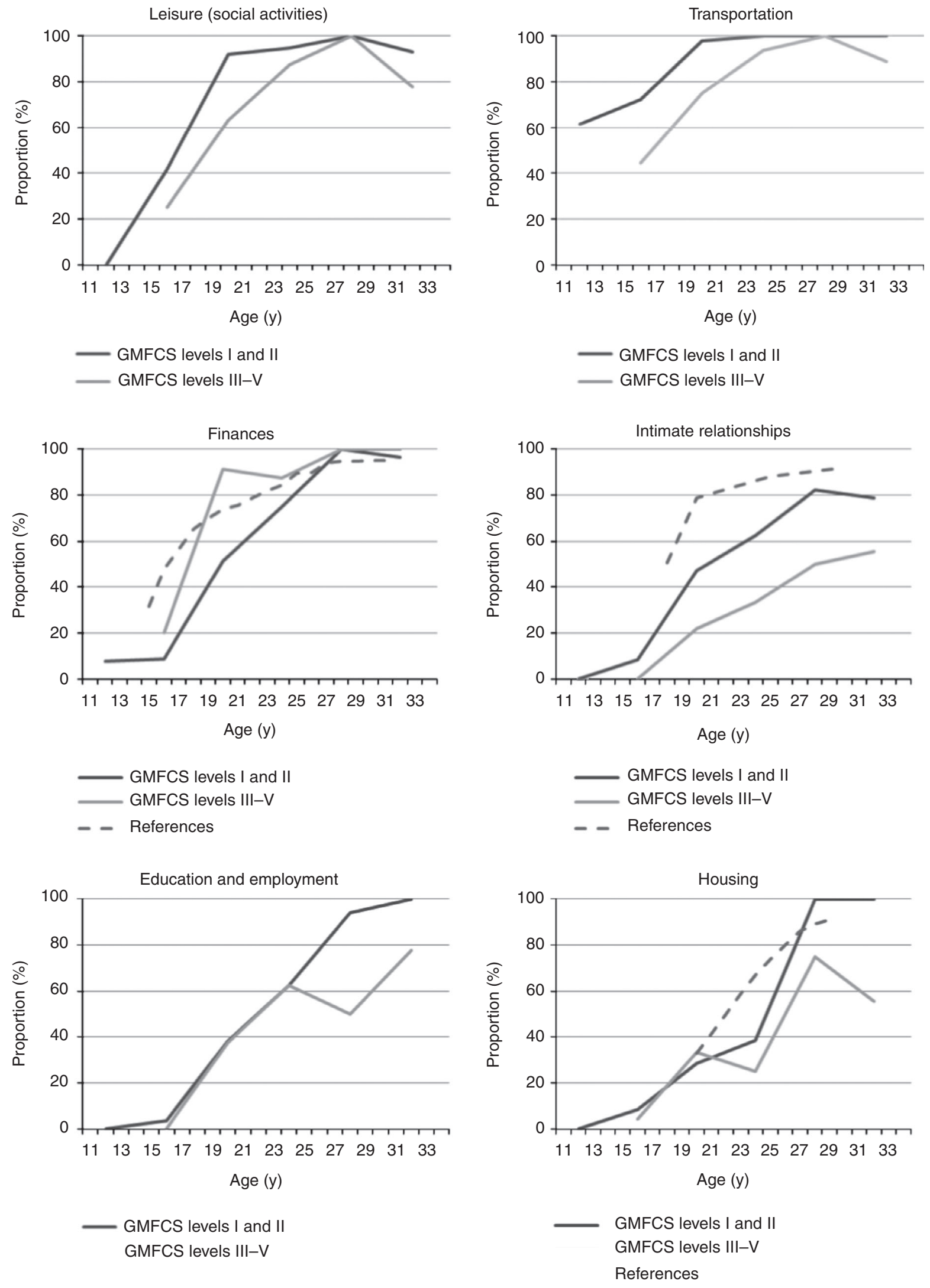

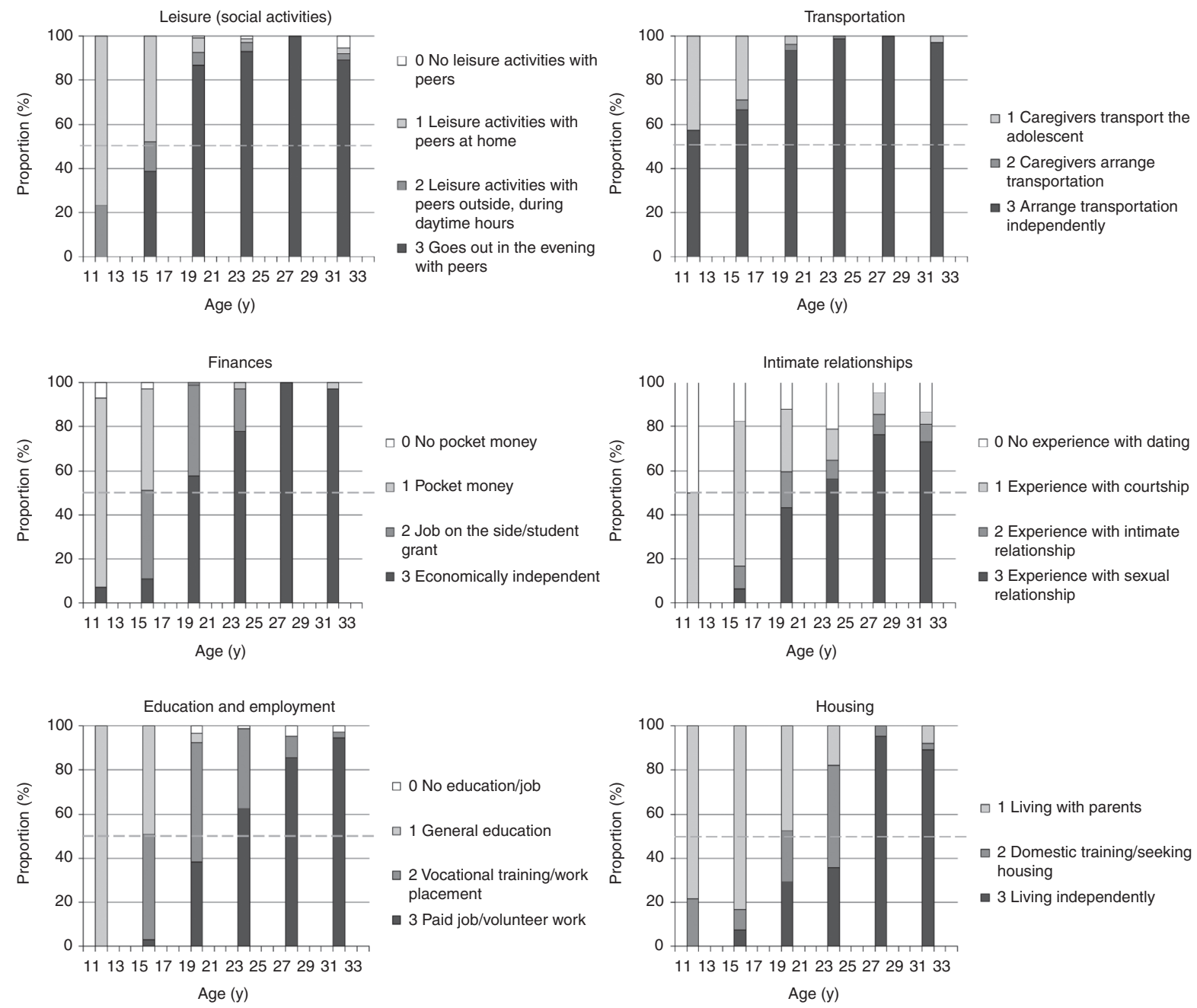

$\square 1$ Living with parents

\ 2 Domestic training/seeking housing

- 3 Living independently

Figure 2: Development of autonomy in participation over time (range 12-34y) for a cohort of young adults with cerebral palsy and without intellectual disability presented in age categories of $4 y$. Number of observations as mentioned in Figure 1. The dashed line indicates the $50 \%$ level. [Correction added on 28 October 2019 after first publication: the figure caption has been updated in this version.]

were autonomous compared to those in GMFCS levels I and II $(\mathrm{OR}=0.12,95 \%$ confidence interval $[\mathrm{CI}]=0.03-0.43$ and $\mathrm{OR}=0.29,95 \% \mathrm{CI}=0.14-0.62$ respectively), regardless of age, since interactions were not significant. This means, for example, that individuals with lower gross motor function have lower odds of organizing their transportation autonomously compared to individuals with higher gross motor function. Notably, for finances, the proportions of autonomous individuals were higher for those in GMFCS levels III to $\mathrm{V}(\mathrm{OR}=5.05,95 \% \mathrm{CI}=1.29-19.77)$, regardless of age. Finally, for employment and housing, development with age differed between individuals in GMFCS levels III to $V$ versus GMFCS levels I and II, as indicated by significant interactions (Table 1). From the late twenties onwards, the development of individuals in GMFCS levels III to V levelled off; therefore, they reached lower proportions of autonomy in employment and housing compared to individuals in GMFCS levels I and II. In their late twenties, on average 64\% of individuals in GMFCS levels III to $\mathrm{V}$ were autonomous in employment and $65 \%$ in housing (Fig. 1).

\section{Comparison with the general population}

We compared the autonomy of individuals with $\mathrm{CP}$ and Dutch aged-matched peers for three domains (Table 2): finances, intimate relationships, and housing. In the 15 to 24 years age range, lower proportions of individuals with $\mathrm{CP}$ were autonomous (according to the RTP) compared to the reference data from the Dutch general population for these domains. For individuals aged 25 years or older, no significant differences were found for finances, whereas for intimate relationships and housing the proportions of autonomous individuals with CP remained lower compared to the Dutch general population at this age. 


\section{DISCUSSION}

This study describes the long-term development of autonomy in participation of individuals with CP without intellectual disability, from childhood into adulthood. With increasing age, more individuals with CP became autonomous in participation; specifically, within each of the domains (with the exception of intimate relationships) over $90 \%$ of the sample reached autonomy in their late twenties. Over the total age range, individuals in GMFCS levels III to $\mathrm{V}$ were less often autonomous in transportation, were more often economically independent (finances), and less often had experience with a sexual relationship (intimate relationships), compared to those in GMFCS levels I and II. In their late twenties, differences emerged between individuals in GMFCS levels I and II and GMFCS levels III to V for employment and housing. Individuals with $\mathrm{CP}$ appeared to lag behind compared to the age-matched Dutch population in finances, intimate relationships, and housing.

An increase of autonomy in participation with increasing age was expected based on the developmental concept of the RTP and an earlier longitudinal study that included part of the present sample. ${ }^{4}$ Lower levels of gross motor function were related to less autonomy in transportation and active sexual relationships over the total age range, but not to financial independence; this is in line with a study conducted in Norway. ${ }^{4,8}$ The finding regarding financial independence is likely due to regulations concerning disability benefits for adults with work limitations (age $\geq 18 \mathrm{y}$ ) in the Netherlands and Norway. For employment and housing, we identified different patterns of development of autonomy for the subgroup with lower gross motor function compared to individuals with higher gross motor function. The proportions of autonomous individuals in GMFCS levels I and II continued to increase with age to almost $100 \%$, whereas a substantial proportion $( \pm 35 \%)$ of individuals in GMFCS levels III to V did not reach autonomy in employment and housing. Therefore, individuals with lower gross motor function are at risk of not achieving autonomy in transportation, intimate relationships, employment, and housing. Rehabilitation professionals should be aware of this and adequately address development of autonomy using personalized treatment.

Compared to their Dutch peers, the total sample of individuals with $\mathrm{CP}$ aged 25 years and younger was less often autonomous in finances, intimate relationships, and housing; this is in line with earlier studies. ${ }^{4,19,23,24}$ The present results also show that, for intimate relationships and housing, individuals with $\mathrm{CP}$ continue to lag behind throughout their early thirties compared to their typically developing peers, whereas for finances the differences with peers decrease above the age of 25 years; this decrease is probably also due to the system of disability benefits in the Netherlands. For the domain of employment, no reference data were compared because the RTP considers work participation including voluntary work, whereas Statistics Netherlands do not. For intimate relationships, the difference between individuals with $\mathrm{CP}$ and the reference data may be even larger since, for the references, experience with intimate relationships was only considered over the previous 12 months. For intimate relationships and housing, overall fewer individuals with $\mathrm{CP}$ reached autonomy, indicating that individuals with CP may benefit from specialized support in these areas. This is confirmed by a need for information and intervention with regard to $\mathrm{CP}$ and sexuality, as expressed by young people with $\mathrm{CP}$ themselves, who reported that sexuality is scarcely discussed in rehabilitation treatment. ${ }^{24} \mathrm{~A}$ specialized group programme might help to address this need. ${ }^{25}$ For housing, specialized support may include residential training for individuals with $\mathrm{CP}$ in their early twenties.

The RTP was used to assess autonomy, which we consider an aspect of participation. The RTP is easily administered (longitudinally) to evaluate the process of transition from adolescence to adulthood; the present results add to the evidence that the RTP can also capture changes with increasing age. In accordance with the definition of autonomy, the RTP covers two dimensions of autonomy, decisional (self-determination) and executional (independence) autonomy. ${ }^{2}$ Additional qualitative studies are required to further elucidate these specific dimensions of autonomy.

\section{Strengths and limitations}

This is the first study to describe the development of autonomy in participation of individuals with CP without intellectual disability over a broad age range, from the teens to the early thirties. Despite substantial dropout since baseline (Appendix S2), our rehabilitation-based sample seems representative of the population since the distributions of sex, GMFCS level, and type of CP are similar to individuals with intellectual disability in population-based studies. ${ }^{26}$ In line with these distributions, we had lower numbers of participants in GMFCS levels III to $\mathrm{V}$, increasing the uncertainty around ORs that compare individuals in GMFCS levels III to $\mathrm{V}$ to those in GMFCS levels I and II. Another limitation is that a substantial part $(46 \%)$ of the sample was assessed cross-sectionally; for those aged 12 to 16 years, only crosssectional observations were available. Therefore, this part of the results is less robust. Since autonomy in participation is influenced by national legislation, for example, regarding social services, sheltered employment, and disability benefits, the present results should be interpreted with caution and estimated proportions may not be generalizable to other countries.

\section{Clinical relevance and recommendations for future research}

The present study offers an insight into the development of autonomy of individuals with CP for several participation domains. The results show that individuals with lower gross motor function are at risk of not achieving autonomy; this should be addressed in rehabilitation care, especially regarding intimate relationships, employment, and 
housing. ${ }^{25,27}$ Future research may add knowledge concerning barriers and facilitators that influence the development of autonomy in different life domains for individuals with $\mathrm{CP}$, as previously investigated for intimate relationships. ${ }^{10,24}$ Since the present study focused on individuals without intellectual disability, future research may also examine the development of autonomy in participation and the needs of individuals with an intellectual disability.

\section{CONCLUSION}

In this study, in most life domains, $90 \%$ of individuals with CP without intellectual disability reached autonomy in adulthood. Over the total age range, individuals in GMFCS levels III to $\mathrm{V}$ were less often autonomous in transportation and intimate relationships compared to those in GMFCS levels I and II. In the late twenties, differences between those in GMFCS levels I and II and GMFCS levels III to $\mathrm{V}$ also emerged in employment and housing. Compared to the aged-matched general population, individuals with CP seem to lag behind in the development of autonomy in their teens until their early thirties. These results urge rehabilitation professionals to address the development of autonomy and help guide expectations, especially in individuals with lower gross motor function with regard to intimate relationships, employment, and housing.

\section{ACKNOWLEDGEMENTS}

Members of the PERRIN-DECADE and PiP study groups are as follows: M. E. Roebroeck, M. van Gorp, S. S. Tan, J. van Meeteren, W. van der Slot, H. Stam (Erasmus MC, University Medical Center and Rijndam Rehabilitation, Rotterdam); A. J. Dallmeijer, L. van Wely, V. de Groot (Amsterdam UMC, Vrije Universiteit Amsterdam); M. Ketelaar, J. M. Voorman, D. W. Smits, S. C. Wintels (University Medical Center Utrecht and De Hoogstraat Rehabilitation, Utrecht); H. A. Reinders-Messelink (Revalidatie Friesland and University Medical Center Groningen); J. W. Gorter (McMaster University, Hamilton, Canada); J. Verheijden (BOSK, Association of Physically Disabled Persons and their Parents).

This study was carried out as part of the PERRIN research programme and was supported by Fonds NutsOhra (no. 1403030) and Rijndam Rehabilitation, Rotterdam, the Netherlands.

The authors have stated that they had no interests that might be perceived as posing a conflict or bias.

\section{SUPPORTING INFORMATION}

The following additional material may be found online:

Appendix S1: Flowchart of participant inclusion

Appendix S2: The Rotterdam Transition Profile (version 2011)

Appendix S3: Figure observations

Appendix S4: Participant characteristics

\section{REFERENCES}

1. Gorter JW, Roebroeck ME. Transition to adulthood: enhancing health and quality of life for emerging adults with neurological and developmental conditions. In: Ronen GM, Rosenbaum PL, editors. Life Quality Outcomes in Children and Young People with Neurological and Developmental Conditions. 1st edn. London: Mac Keith Press, 2013: 302-13.

2. Cardol M, De Jong BA, Ward CD. On autonomy and participation in rehabilitation. Disabil Rebabil 2002; 24 : $970-4$

3. World Health Organization. International Classification of Functioning, Disability and Health: ICF. Geneva: World Health Organization, 2001.

4. Donkervoort M, Wiegerink DJ, van Meeteren J, et al. Transition to adulthood: validation of the Rotterdam Transition Profile for young adults with cerebral palsy and normal intelligence. Dev Med Child Neurol 2009; 51: 53-62.

5. Rosenbaum P, Paneth N, Leviton A, et al. A report: the definition and classification of cerebral palsy April 2006. Dev Med Child Neurol Suppl 2007; 109: 8-14.

6. Brooks JC, Strauss DJ, Shavelle RM, Tran LM, Rosenbloom L, Wu YW. Recent trends in cerebral palsy survival. Part I: period and cohort effects. Dev Med Child Neurol 2014; 56: 1059-64.

7. Zhang-Jiang S, Gorter JW. The use of the Rotterdam Transition Profile: 10 years in review. 7 Transit Med 2018; 110: 1307-14.

8. Ingebrigtsen $T$. Effects of gross motor functioning and transition phase on health related quality of life in
Norwegian adolescents with cerebral palsy [Thesis] Trondheim: NTNU, 2015.

9. van Gorp M, Roebroeck ME, Swan Tan S, et al. Activity performance curves of individuals with cerebral palsy. Pediatrics 2018; 142: e20173723.

10. Wintels SC, Smits DW, van Wesel F, et al. How do adolescents with cerebral palsy participate? Learning from their personal experiences. Health Expect 2018; 21: 1024-34.

11. van Eck M, Dallmeijer AJ, Voorman JM, Becher JG. Longitudinal study of motor performance and its relation to motor capacity in children with cerebral palsy. Dev Med Child Neurol 2009; 51: 303-10.

12. Ketelaar M, Gorter JW, Westers P, Hanna S, Verhoef M. Developmental trajectories of mobility and self-care capabilities in young children with cerebral palsy. 7 Pediatr 2014; 164: 769-74.

13. Smits DW, Gorter JW, Ketelaar M, et al. Relationship between gross motor capacity and daily-life mobility in children with cerebral palsy. Dev Med Child Neurol 2010; 52: e60-6.

14. Tellegen P, Winkel M, Wijnberg-Williams B, Laros J. Snijders-Oomen Niet Verbale Intelligentietest SON-R. Handleiding en verantwoording. [The Snijders-Oomen nonverbal intelligence tests SON-R. Manual and Research Report] Lisse, the Netherlands: Swets \& Zeitlinger, 1998.

15. Raven J, Raven JC, Court JH. Manual for Raven's Progressive Matrices and Vocabulary Scale. Section 2: Coloured Progressive Matrices. Oxford: Oxford Psychologists Press, 1998.
16. Statistics Netherlands. Standaard onderwijsindeling, 2016/2017 edn. [The Dutch Standard Classification of Education, 2016/2017 edn]. Den Haag/Heerlen: Statistics Netherlands, 2018.

17. Cans C. Surveillance of cerebral palsy in Europe: a collaboration of cerebral palsy surveys and registers. Dev Med Child Neurol 2000; 42: 816-24.

18. Palisano R, Rosenbaum P, Walter S, Russell D, Wood E, Galuppi B. Development and reliability of a system to classify gross motor function in children with cerebral palsy. Dev Med Child Neurol 1997; 39: 214-23.

19. Sattoe JN, Hilberink SR, van Staa A, Bal R. Lagging behind or not? Four distinctive social participation patterns among young adults with chronic conditions. $f$ Adolesc Health 2014; 54: 397-403.

20. Statistics Netherlands.Arbeidsdeelname; kerncijfers geboortegeneratie vanaf 1910 tot 1915. [Labour participation; key figures by birth generation since 1910 to 1915]. [Internet]. Den Haag/Heerlen: Statistics Netherlands. https://opendata.cbs.nl/statline/\#/CBS/nl/dataset/ 83294NED/table?ts=1567451913360 (accessed 29 August 2019).

21. Statistics Netherlands. Het leven van twintigers [Internet]. Den Haag/Heerlen: Statistics Netherlands. https:// www.cbs.nl/-/media/imported/documents/2015/10/ 2015-het-dynamische-leven-van-twintigers.pdf (accessed 29 August 2019).

22. Nederland RaSA. Kerncijfers leefstijlmonitor seksuele gezondheid 2015. [Key figures lifestyle monitor sexual 
health 2015]. Utrecht, the Netherlands: Rutgers and Soa Aids Nederland, 2017.

23. Michelsen SI, Flachs EM, Damsgaard MT, et al. European study of frequency of participation of adolescents with and without cerebral palsy. Eur 7 Paediatr Neurol 2014; 18: 282-94.

24. Wiegerink D, Roebroeck M, Bender J, Stam H, Cohen-Kettenis P, Transition Research Group South West Netherlands. Sexuality of young adults with cerebral palsy: experienced limitations and needs. Sex Disabil 2011; 29: 119-28.

25. Hilberink SR, Kruijver E, Wiegerink DJHG, Vliet Vlieland TPM. A pilot implementation of an intervention to promote sexual health in adolescents and young adults in rehabilitation. Sex Disabil 2013; 31: 373-92.

26. Himmelmann K, Beckung E, Hagberg G, Uvebrant P. Gross and fine motor function and accompanying impairments in cerebral palsy. Dev Med Child Neurol 2006; 48: 417-23.

27. Verhoef JA, Miedema HS, Van Meeteren J, Stam HJ, Roebroeck ME. A new intervention to improve work participation of young adults with physical disabilities: a feasibility study. Dev Med Child Neurol 2013; 55: 722-8. 


\section{RESUMEN}

\section{AUtONOMía EN LA PARTICIPACIÓN EN LA PARÁlISIS CEREBRAL DESDE LA INFANCIA A LA EDAD ADULTA}

\section{OBJETIVO}

Determinar el desarrollo a largo plazo de la autonomía en la participación de individuos con parálisis cerebral (PC) sin discapacidad intelectual.

\section{MÉTODO}

Individuos con PC ( $n=189,117$ varones, 72 mujeres; edad media [DE] 21 años y 11 meses [4 años y 11meses], rango 12-34 años): fueron evaluados de forma transversal (46\%) o hasta cuatro veces (54\%), entre las edades comprendidas entre los 12 y los 34 años. La autonomía en la participación fue clasificada usando la fase 3 del perfil de transición de Rotterdam (Rotterdam Transition Profile). Se utilizó un modelo de regresión logístico generalizado estimando la ecuación para analizar la autonomía en 6 dominios (variables independientes: edad, nivel del Sistema de Clasificación de la Función Motora Gruesa, [GMFCS], y la interacción entre la edad y el nivel GMFCS). Las proporciones de la autonomía se compararon con las referencias mediante pruebas binomiales $(p<0,05)$.

\section{RESULTADOS}

En la mayoría de los dominios, más del $90 \%$ de los participantes ( $n=189.400$ observaciones, $80 \%$ en los niveles I y II de la GMFCS) alcanzaron la autonomía en la participación bien entrados los 20 años, excepto para las relaciones íntimas/sexuales. Aquellos en los niveles III y V de la GMFCS en comparación con los niveles I y II de la GMFCS tuvieron un desarrollo de la autonomía menos favorable en el transporte, relaciones íntimas, empleo y en el dominio de la vivienda, y un desarrollo más favorable en el dominio de las finanzas. En comparación con las referencias, menos individuos con PC fueron autónomos en la participación.

\section{INTERPRETACIÓN}

Este conocimiento de la autonomía puede guiar las expectativas de los jóvenes con PC y de sus cuidadores. Además, los profesionales de la rehabilitación deberían abordar el desarrollo de la autonomía en las relaciones íntimas, el empleo y la vivienda, especialmente en aquellos individuos con una función motora gruesa más baja.

\section{RESUMO}

\section{AUTONOMIA NA PARTICIPAÇ̃̃ EM PARALISIA CEREBRAL DA INFÂNCIA À VIDA ADULTA}

\section{OBJETIVO}

Determinar o desenvolvimento em longo prazo da autonomia na participação de indivíduos com paralisia cerebral (PC) sem deficiência intelectual.

\section{MÉTODO}

Indivíduos com PC ( $n=189,117$ do sexo masculino, 72 do sexo feminino; média de idade [DP] 21a 11m [4a 11m], variação 12-34a); foram avaliados transversalmente (46\%) ou até quatro vezes (54\%), entre as idades de 12 e 34 anos. A autonomia na participação foi classificada usando a fase 3 do Perfil de Transição de Rotterdam. Um modelo de regressão logística com generalizada com equações estimadas foi usado para analisar a autonomia em seis domínios (variáveis independentes: idade, Nível segundo o Sistema de Classificação da Função Motora Grossa [GMFCS], e interação entre idade e nível GMFCS). As proporções de autonomia foram comparadas com as referências usando testes binomiais $(p<0,05)$.

\section{RESULTADOS}

Na maior parte dos domínios, cerca de $90 \%$ dos participantes ( $n=189.400$ observações, $80 \%$ nos níveis GMFCS I e II) atingiram autonomia na participação no final da terceira década de vida, exceto para relações íntimas/sexuais. Aqueles nos níveis GMFCS III a V comparados com os níveis I e II tiveram desenvolvimento menos favorável nos domínios da autonomia no transporte, relações íntimas, emprego, e domicílio, e mais desenvolvimento mais favorável no domínio das finanças. Em comparação com as referências, menos indivíduos com PC foram autônomos na participação.

\section{INTERPRETAÇ̃̃O}

Este conhecimento sobre a autonomia pode guiar as expectativas de jovens com PC e seus cuidadores. Além disso, profissionais da reabilitação devem abordar o desenvolvimento da autonomia nas relações íntimas, emprego e domicílio, especialmente nos indivíduos com menor função motora grossa. 